\title{
Addison's Disease and Diabetes Mellitus
}

\author{
A. P. KENNA \\ From Alder Hey Hospital, Liverpool, and the Department of Child Health, University of Liverpool
}

The combination of Addison's disease with diabetes mellitus is a rare event, and most cases described have been in adults. The association of the two diseases is intrinsically interesting because of their metabolic interrelationships, quite apart from the rarity of its occurrence.

\section{Case Report}

The patient is a boy who was first seen at the age of 11 years. His paternal great-grandfather was a diabetic of maturity-onset type; his maternal grandmother in later years was said to have been extremely dark-skinned, and to have had a craving for salt.

He had been quite well until a month earlier, when he became lethargic, anorexic, and unduly thirsty. At this time no polyuria was noted; his parents thought that he appeared rather surprisingly 'sun tanned'. He began to suffer from vomiting which became more and more persistent, and a polyuria was observed. He was also experiencing occasional bouts of faintness when standing upright.

Because of these symptoms, he was admitted to Whiston Hospital under the care of Dr. R. H. WhiteJones, where he was found to be dehydrated, and to have pigmented skin and gums. There was sugar, but no acetone in his urine. His blood sugar was $533 \mathrm{mg} . / 100$ $\mathrm{ml}$. He was treated with insulin and intravenous fluids, and within 24 hours his blood sugar was within normal limits. A glucose tolerance test then confirmed the diagnosis of diabetes mellitus, showing a fasting sugar level of $127 \mathrm{mg} . / 100 \mathrm{ml}$., rising to $300 \mathrm{mg} . / 100 \mathrm{ml}$. at 2 hours.

His hyperglycaemia proved remarkably easy to control, as he needed only 10 units of IZS lente insulin every 3 days to keep his blood sugar within an acceptable range. No ketone bodies were found in his urine on this régime.

Despite this apparently satisfactory response, his clinical condition remained far from good. He continued to vomit and to be extremely lethargic. His blood pressure remained at the rather low level of $80 / 50 \mathrm{~mm}$. $\mathrm{Hg}$ which had been found on admission.

This situation, together with the pigmentation, led to the suspicion of a concomitant Addison's disease, but his serum sodium and chloride values were found to be normal, and the diagnosis could not be confirmed at this stage. One month after his admission he was, therefore,

Received September 9, 1966. transferred to Alder Hey Hospital under the care of Dr. R. M. Todd for further study, where he was found to be pigmented as described, extremely lethargic, and with a blood pressure of $90 / 50 \mathrm{~mm}$. Hg. This time, however, his electrolytes were in keeping with a diagnosis of Addison's disease, as the serum $\mathrm{Na}$ was $111 \mathrm{mEq} / \mathrm{l}$., $\mathrm{K} 5.2 \mathrm{mEq} / 1$., and $\mathrm{Cl} 85 \mathrm{mEq} / \mathrm{l}$. The blood sugar was $135 \mathrm{mg}$. $/ 100 \mathrm{ml}$. Blood urea was $125 \mathrm{mg}$. $/ 100 \mathrm{ml}$.

An ACTH stimulation test gave the results shown in the Table.

His clinical condition during this period of study gave rise to considerable anxiety, as he continued to vomit periodically, and to be extremely lethargic. His blood pressure remained at $80 / 50-90 / 50 \mathrm{~mm}$. $\mathrm{Hg}$ and his serum $\mathrm{Na}$ remained low, 108-121 mEq/1., despite the administration of DOCA $1 \mathrm{mg}$. b.d. i.m. On several occasions he had intravenous saline infusions. Throughout this period, his blood sugar levels remained within normal limits, and there was no acetonuria. Significantly, he did not require any insulin at all.

TABLE Results of ACTH Stimulation Test

\begin{tabular}{|c|c|c|}
\hline Day & & 17-OH Corticoids \\
\hline $\begin{array}{l}1 \\
2 \\
3 \\
4 \\
5\end{array}$ & $\begin{array}{ll} & \text { Baseline } \\
2 \times 30 \text { units ACTH } \\
2 \times 30 \text { units ACTH } \\
2 \times 30 \text { units ACTH } \\
\text { Nil }\end{array}$ & $\begin{array}{l}<0.1 \mathrm{mg} . \text { per day } \\
<0.1 \mathrm{mg} . \text { per day } \\
<0.1 \mathrm{mg} \text {. per day } \\
<0.1 \mathrm{mg} \text {. per day } \\
<0.1 \mathrm{mg} \text {. per day }\end{array}$ \\
\hline
\end{tabular}

Once the ACTH test was completed, the results were thought to show conclusively that his adrenal cortex was not putting out any measurable quantity of hydroxycorticoids either at rest or in response to exogenous ACTH, thus confirming the diagnosis of Addison's disease.

He was therefore started on prednisolone $5 \mathrm{mg}$. daily and $9-\alpha$-fluoro-hydrocortisone $0.1 \mathrm{mg}$. daily. As a result he stopped vomiting and his clinical condition improved.

The biochemical changes are shown on the chart (Fig.). His serum electrolytes did not stabilize at a satisfactory level until the dose of 9- $\alpha$-fluoro-hydrocortisone was increased to $0.1 \mathrm{mg}$. twice daily. The blood sugar level had risen to $560 \mathrm{mg}$. $/ 100 \mathrm{ml}$. after 4 days on therapy, and he was therefore put on soluble insulin 18 units b.d.

Ten days after starting steroids he was vastly improved, 


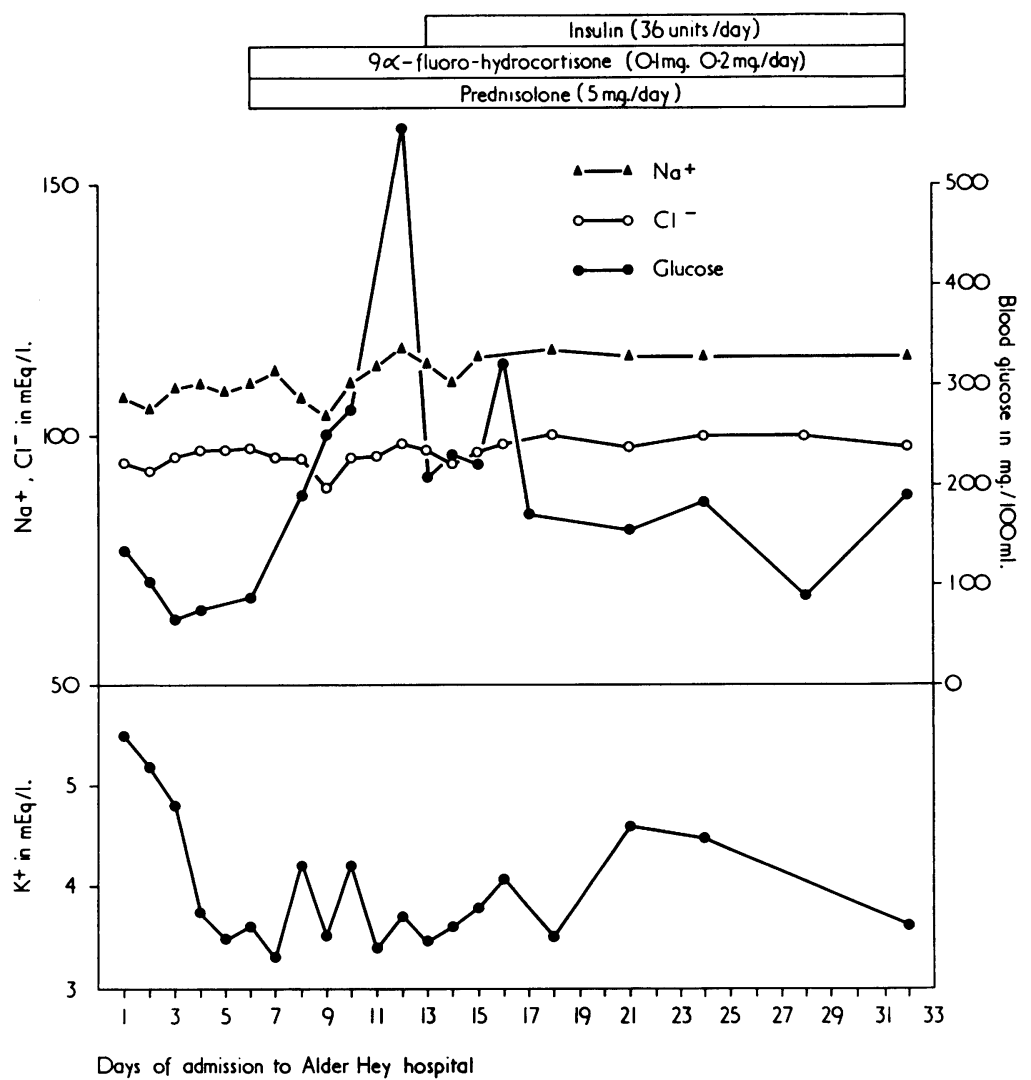

Fig.-Serum $\mathrm{Na}^{+}, \mathrm{K}^{+}, \mathrm{Cl}^{-}$, and blood sugar levels. The daily dose of the drugs is shown.

eating well, and was extremely lively. As the glycosuria was now well controlled, he was converted to a régime of IZS lente insulin 36 units daily with a carbohydrate intake of $210 \mathrm{~g}$. daily. On this diabetic régime, together with prednisolone $5 \mathrm{mg}$. daily and 9- $\alpha$-fluoro-hydrocortisone $0.1 \mathrm{mg}$. twice daily, he was discharged home. Since then his progress has been satisfactory. His insulin requirements have increased a little, and he is at present taking 40 units of IZS lente insulin. The pigmentation has decreased greatly since discharge, and he enjoys full activity.

The cause of this boy's condition remains unknown. No tuberculous aetiology for his Addison's disease could be demonstrated as his chest $x$-ray film was normal, and there was no intra-abdominal calcification. His Mantoux test (1 : 1000) was negative. Haemachromatosis was excluded by finding a normal serum iron level and the absence of hepatosplenomegaly.

There was no evidence of any other endocrine lesion and his protein-bound iodine was $7 \cdot 1 \mu \mathrm{g} . / 100 \mathrm{ml}$.

\section{Discussion}

The combination of Addison's disease with diabetes mellitus is a rare event but one which is being reported with increasing frequency. Wehrmacher (1961) pointed out that the first case was reported in 1866 by Ogle, but by 1941 only 15 cases had been reported. In 1959 a detailed survey of all published cases was produced by Beaven, Nelson, Renold, and Thorn, and at that time reports on 73 cases were extant of which only 3 were in children under 15 (Stanton, Jones, and Marble, 1954; Simpson, 1932; Gould and Shlevin, 1955). Further cases have been reported since (Leahy, 1959; $\mathrm{McNicol}$ and McNicol, 1960; Selby, 1962; Ezrin and Nicholas, 1962; Bourne and Howard, 1963; Knox, 1962; Cantor, 1964; Csapó, Dávid, and Kovács, 1963; Moorehead, De Crinis, Jahsman, and Drummond, 1964), of which only one is a child under 15 (Burke and Emanuel, 1965). The present total number is probably about 90 .

The age range of these cases is fairly wide, from 10-76 years, but the commonest age was the late twenties and early thirties. Only one patient had both diseases at such an early age as ours (Stanton et al., 1954). 
Beaven et al. (1959) showed that the commonest way for this combination to present was that of Addison's disease developing in an established diabetic (57\% of all cases). Diabetes developed in a known case of Addison's disease in $26 \%$, and both diseases seemed to occur together in only $9 \%$.

Our case is, therefore, remarkable not only in the early age at which both conditions developed, but for the mode of presentation.

There does not seem to be any reason why these two diseases should occur together with an increasing frequency. The known susceptibility of diabetics to tuberculosis could offer an explanation of why they should be prone to develop Addison's disease, but tuberculosis is in fact an increasingly infrequent cause of Addison's disease, and in those cases in which information could be obtained, was not established as a significant factor in Beaven's series. Presumably modern methods of treatment are allowing patients with one of these diseases to survive long enough to have a chance of developing the other. There may also be an increasing frequency of diagnosis of Addison's disease due to the availability of more sophisticated laboratory techniques.

The metabolic interrelationships have been well described by Gittler, Fajans, and Conn (1959). Because it stimulates gluconeogenesis and inhibits peripheral utilization of glucose, hydrocortisone has an opposing effect to insulin on carbohydrate metabolism. Thus, in the commoner situation, where Addison's disease develops in an established diabetic, the features are that there is a marked reduction in insulin requirements, together with an increased resistance to ketosis. However, there is increased instability of blood sugar level, and an increased tendency to hypoglycaemia. Despite this apparent improvement, the patient's clinical condition deteriorates markedly because of the lack of control of the Addison's disease. Once this is treated, the diabetic state reverts sharply to its previous state. These features of the interaction of the two conditions are well brought out in the present case.

In the situation where diabetes develops in a known case of Addison's disease, the patient's condition deteriorates in a way that suggests a deterioration in an Addisonian state. There is anorexia, weight loss, lassitude, and low blood pressure. If the true state of affairs is not realized, the patient may be given increased doses of steroids which will only make things worse. Larger doses of salt-retaining hormones are equally useless.

The more unusual combined pattern will present the problem described here-a patient who is ill with symptoms and signs suggestive of one or another of these two disorders, yet associated with some contradictory findings, and curious responses to therapy, such as severe hypoglycaemia in response to insulin therapy of normal intensity.

The possibility of both conditions being present should be borne in mind, especially in the numerically commoner situation of a diabetic who experiences unexplained reduction of insulin requirements together with apparent freedom from ketosis.

\section{Summary}

An 11-year-old boy is described who presented with manifestations of both Addison's disease and diabetes mellitus. The increasing frequency of this association is commented upon, and the metabolic interrelationships of the two conditions are briefly discussed.

I would like to thank Dr. R. M. Todd for permission to publish this case, and for helpful advice in the preparation, and Dr. E. G. Hall and Mr. J. T. Ireland for the biochemical estimations.

\section{REFERENCES}

Beaven, D. W., Nelson, D. H., Renold, A. E., and Thorn, G. W. (1959). Diabetes mellitus and Addison's disease: a report on 8 patients and a review of 55 cases in the literature. New Engl. F. Med., 261, 443.

Bourne, F. M., and Howard, R. P. (1963). Addison's disease complicating diabetes. Canad. med. Ass. F., 88, 365.

Burke, G., and Emanuel, B. (1965). Addison's disease and diabetes mellitus in an adolescent. Clin. Pediat. (Philad.), 4, 543.

Cantor, A. M. (1964). Simultaneous onset of diabetes mellitus and Addison's disease: a case report. F. Irish. med. Ass., 53, 77.

Csapó, G., Dávid, M. A., and Kovács, K. (1963). Development of diabetes mellitus in a patient suffering from Addison's disease. Acta med. scand., 174, 321.

Ezrin, C., and Nicholas, W. C. (1962). Atypical Addison's disease in a patient with diabetes mellitus. Canad. med. Ass. F., 86, 584.

Gittler, R. D., Fajans, S. S., and Conn, J. W. (1959). Coexistence of Addison's disease and diabetes mellitus: report of 3 cases with a discussion of metabolic interrelationships. $\mathcal{F}$. clin. Endocr., 19, 797.

Gould, K. S., and Shlevin, E. L. (1955). Addison's disease complicating diabetes mellitus in adolescence. Ann. intern. Med., 43, 1092.

Knox, E. W. (1962). Diabetes mellitus and Addison's disease. Ulster. med. F., 31, 175.

Leahy, J. (1959). Addison's disease and diabetes mellitus. $\mathcal{F}$. Irish med. Ass., 45, 178.

McNicol, G. P., and McNicol, M. W. (1960). Addison's disease complicated by diabetes mellitus. Scot. med. F., 5, 30.

Moorehead, M. T., De Crinis, K. A., Jahsman, D. P., and Drummond, T. A. (1964). Addison's disease complicated by diabetes mellitus. Calif. Med., 100, 365.

Ogle, J. W. (1866). On disease of the brain as a result of diabetes mellitus. St. Georges Hosp. Rep., 1, 157.

Selby, J. B. (1962). Addison's disease associated with diabetes mellitus. Amer. Practit., 13, 347.

Simpson, S. L. (1932). Addison's disease and its treatment by cortical extract. Quart. F. Med., 1, 99.

Stanton, E. R., Jones, H. W., Jr., and Marble, A. (1954). Coexisting diabetes mellitus and Addison's disease. Observations and report of a case in a 10-year-old boy. Arch. intern. Med., 93, 911.

Wehrmacher, W. H. (1961). Addison's disease with diabetes mellitus. ibid., 108, 114 . 